\title{
THE EFFECT OF VOCABULARY TOWARDS WRITING SKILL WITH READING SKILL AS MODERATING EFFECT
}

\author{
1Paskalina Widiastuti Ratnaningsih ${ }^{2}$ Catharina Clara \\ 1 Universitas Dinamika Bangsa, Indonesia; \\ ${ }^{2}$ Universitas Katolik Musi Charitas, Indonesia
}

Corresponding email: paskalina.widiastuti.r@gmail.com

\begin{abstract}
Vocabulary is one of the English components that need to be mastered for acquiring writing and reading. Writing needs various vocabularies to build different sentences. Reading needs understanding of different meaning of vocabularies based on the context in the sentence. Hence, vocabulary is important in English language learning to support writing and reading. Regarding the importance of vocabulary, writing, and reading, the aim of this research is to test the effect of vocabulary mastery towards writing ability in English. It is also to test moderating effect of reading ability in strengthening or weakening the relation. This study used moderated regression analysis (MRA). Then, this research used the test as research instrument. The instruments had been valid and also reliable. Classical assumption tests were used before the research analysis. The samples were Management students of semester four and six. Descriptive analysis towards each variable is used to know students' ability in English. To analyze the effect of independent variables towards dependent variable, it used linear regression analysis. To analyze moderating effect, it used moderating regression analysis. From this research result, it was proved that vocabulary had positive significant effect towards writing skill. Reading skill moderated the relation of vocabulary towards writing skill. Further research can focus on experimental research of vocabulary, writing, and reading.
\end{abstract}

Keywords: Vocabulary, Reading Skill, Writing Skill, Moderating Effect

\section{INTRODUCTION}

In industrial revolution 4.0., the students are expected not only able to speak well but also to write well. Moreover, the students of university are also encouraged to read and write well for preparing their thesis. Hence, vocabulary is chosen as the English component to write well with reading skill as writing enhancement. 
Vocabulary plays an important role in writing. Nation in Alqahtani (2015, p. 22) states that "In English as a second language (ESL) and English as a foreign language (EFL) learning vocabulary item plays a vital role in all language skills, i.e., listening, speaking, reading, and writing". It means that vocabulary is needed to learn English skills. Nation in Solati-Dehkordi and Dehkardi (2016) also states that vocabulary relates to written form of a word. Hence, writing which consists of a set of words in sentences and paragraphs needs good written form of words. Raims in Solati-Dehkordi and Dehkardi (2016) states that individuals that do not have good vocabulary mastery have problems in writing. It means that vocabulary as one of the keys in writing. Vocabulary is also important for reading. Smith in Nurdini and Marlina (2017) states that readers search in the dictionary for the words that they do not know the meaning while reading. Cline in Ariana (2018) also states that reading is part of understanding the meaning from the text.

Vocabulary is presented in six ways based on Thornbury (2002). The first is by presenting vocabulary. Teaching is the way to present vocabulary. The second is using translation. The translation is from first language into second language. The third is on how to illustrate meaning. The illustration can be in the form of picture, real object, or mime. The fourth is on how to explain meaning. It is by using non-visual or verbal means. The fifth is on how to highlight the form. The spoken form is highlighted. The sixth is on how to involve learners. The involvement of the student is with elicitation, nominating, personalization, and association network.

According to Thornbury (2002), there are several ways to test vocabulary. Based on types of tests, there are three types. They are multiple choice, gap-fill, selective (or open) cloze type. Further, based on measuring word knowledge, there are three types. They are lexical density, lexical variety, and lexical sophistication. Then, based on assessing vocabulary size, there are five types. They are 700, 1200, 1500, 3200, and 8100 most frequent words.

Reading is also needed in the process of writing. Krashen in Khoirunissa and Safitri (2018) states that continuous reading can enhance English skill performance including writing. Hence, reading is important to be learned in relation with learning writing. Reading skill is chosen since students need to be able to read well before writing.

There are ten strategies to teach reading based on Brown (2007). They are: 1) to identify the purpose in reading; 2) to use graphemic rules and patterns to aid in bottom-up decoding; 3) to use efficient silent reading techniques for improving fluency; 4) to skim the text for main ideas; 5) to scan the text for specific information; 6) to use semantic mapping or clustering; 7) to guess what it is not certain; 8) to analyze vocabulary; 9) to distinguish 
between literal and implied meanings; and 10) to capitalize on discourse makers to process relationships.

Vocabulary and reading relate to writing. Writing involves seven characteristics of written language as stated by Brown (2007). Permanence of the final writing form can still be clarified. Production time of writing happens through process until final version. Writing must consider distant audience for having interpretation. It needs orthography in which writing involves simple to complex ideas. Writing also involves complexity skills in reducing redundancy, combining sentences, making inferences, and creating lexical types. Then, writing involves vocabulary use. The last is writing involves formal type of writing.

Teaching writing has six principles according to Brown (2007). Writing needs practice to produce good writing. Writing also needs process starting from making draft until it becomes product. Since writing in second language needs literary background, the teacher needs to introduce it to the students. Afterwards, reading connects to writing. Hence, students need to have good reading before writing. Authenticity in writing is needed to make the product become original. The last is synchronization of prewriting, drafting, and revising.

There are four previous studies. Aida and Widiyati (2020) did a research on extensive reading to improve students' writing of explanation text in which the result was extensive reading improved writing. Related to Khairunas, Pratama, Iswanto (2019), they did a research on the effect of learning motivation and vocabulary mastery towards students ${ }^{\text {ee }}$ writing skill in argumentative text in which the result was there was significant effect of learning motivation and motivation towards writing skill. Dehkordi and Salehi (2016) did a research on impact of explicit vocabulary instruction on writing achievement in which the result was more practice on vocabulary productivity was needed for writing. Hastuti (2015) did a research on the effect of vocabulary and grammar mastery towards writing skill in which the result was vocabulary and grammar had positive influences towards writing skill. From the previous studies, there is no research yet that uses reading skill as moderating effect in the relation of vocabulary and writing skill. Hence, this study would like to fill the gap to discover this part.

This study was limited in four terms. Firstly, this study was limited in the context of Palembang. In Palembang, this study was implemented in Universitas Katolik Musi Charitas. Secondly, the English component used in this study was limited to vocabulary. Thirdly, the English skills used in this study were limited to writing skill and reading skill. Fourthly, the test could not be done in the classroom with supervision, but the test was conducted online by using Google Form since the data in this study were collected 
during Covid 19 pandemic period in which all students learned from home. Hence, the test was conducted online and not in the classroom.

Considering the importance of vocabulary and reading skill for writing skill, the writers focus the study on the effects of vocabulary towards writing skill with reading skill as moderating effect.

The research questions in this study are:

1) Is there effect of vocabulary towards writing skill?

2) Does reading skill have significant role as moderating effect on the effect of vocabulary towards writing skill?

Hence, after conducting this study, the effect of vocabulary towards writing skill with reading skill as moderating effect is discovered in the teaching-learning activities.

Research Model

Based on the phenomena given, the research model is as follows:

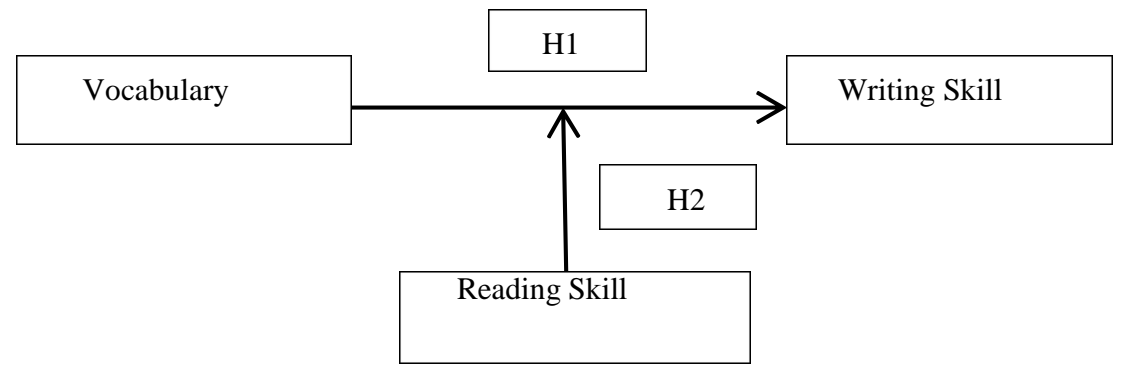

Figure 1. Research Model

From the figure above, it can be seen that vocabulary as the independent variable gives effects on writing skill. The reading skill in this study is as moderating effect that strengthens the influences.

Hypotheses

Based on the research model above, the hypotheses in this study can be seen below:

H1: There is an effect of vocabulary towards writing skill

$\mathrm{H} 2$ : There is a significant role of reading skill as moderating effect on the effect of vocabulary towards writing skill

\section{METHODS}

\section{Participants / Subject / Population and Sample}

The population in this study were all students of the Management study program at the Musi Charitas Catholic University. The total respondent in this 
study was 87 students of Management study program. The respondents were chosen based on nonprobability sampling and purposive sampling. Semester 4 students were considered capable enough in English since they had passed English in Economics course. Whereas, semester 6 students that were conducting seminar were expected to have frequent reading on literature and management field of studies in English.

\section{Instruments}

The instrument in this research was test. The tests in this study were vocabulary test, reading test, and writing test. The vocabulary test and reading test used closed questions, while the writing test used open-ended questions, where respondents were asked to write in English as many as 8-10 sentences about a particular topic in the field of economics. The test was validated first and then it was continued with reliability test for the instrument. Because of the situation and condition of Covid 19 pandemic in which teaching-learning activity was conducted online from home, then the data collection was also conducted online. The test was given with Google Form and distributed the link of Google through Whatsapp group in each class in which the students were the samples in this study. The influence of independent variables and the strengthening of moderating effect were measured with test. The test was in the form of intelligence test. According to Creswell (2012), intelligence test is "a test that measures an individual's intellectual ability".

\section{Data Analysis Procedures}

Technique for data analysis in this study were linear regression and moderated regression analysis (MRA). Ghozali (2016) states that regression is used to measure the relation strength between two or more variables. Ghozali (2016) also states that moderating variable is independent variable that strengthens or weakens the relation of independent variables towards dependent variables. The independent variable in this study is vocabulary, while the dependent variable in this study is writing. Moderating regression analysis is used since there is moderating effect which is reading skill.

The study was started by making test questions. Since the samples in this study were Management students, then the test questions of vocabulary, reading, and writing were made in Economics perspective. After that, the test was distributed to the students with online test by using Google Form. Then, the test answers in Google Form responses were scored. There were three total scores, namely Vocabulary total score, Reading total score, and Writing total score. The respondents' data were also described.

The classical assumption tests were conducted. They were normality test, heteroscedasticity test, and multicollinearity test (between independent 
and moderating variable). Validity and reliability of each test were also conducted.

Afterward, regression was conducted. Firstly, linear regression was conducted to discover the effect of vocabulary towards writing skill. This answered research question 1 and hypothesis 1 . Secondly, moderating regression analysis was conducted to discover the effect of reading skill as moderator effect in the relation of vocabulary towards writing skill. This answered research question 2 and hypothesis 2 .

The data from test results were analyzed. The first was scoring the test. The score results were from vocabulary, reading, and writing tests. Mean score was used as descriptive statistics. The second was to analyze the effect of independent variable to dependent variable (hypothesis 1) with linear regression. It used SPSS version 20. The third was to analyze moderating effect (hypothesis 2). Validity, Reliability, and Classical assumptions test were conducted before having regression.

Moderated Regression Analysis (MRA) used an analytical approach that maintained sample integrity and provided a basis for controlling the influence of moderator variables. To use MRA with one predictor variable $(X)$, three regression equations had to be compared to determine the type of moderator variable (Ghozali, 2016; Sekaran \& Bougie, 2017). The Reading Skill (RS) variable was a pure moderator variable on effect of vocabulary to writing skill if (1) and (2) were not different, but it had to be different from equation (3).

The reading skill variable was a quasi-moderator variable if (1), (2) and (3) had to differ from one another. The reading skill variable was not a moderator variable if (2) and (3) were not significantly different. To test the effect of reading skill moderation on the effect Vocabulary to writing skill, it used comparison of equation 1 with equations 2 and 3.

$$
\begin{gathered}
\text { WS }=\alpha+\beta 1 \text { Vocabulary }+\varepsilon \quad(1) \\
\text { WS }=\alpha+\beta 1 \text { Vocabulary }+\beta 2 R S+\varepsilon \quad(2) \\
W S=\alpha+\beta 1 \text { Vocabulary }+\beta 2 R S+\beta 3 \text { Vocabulary } \times R S+\varepsilon(3)
\end{gathered}
$$

\section{FINDINGS}

\section{Respondents' Characteristics}

There were 87 test results out of 120 students that were valid and filled in completely that could be used to do further testing and analysis. Whereas 33 more test results could not be analyzed further because of several reasons, such as the test was not filled completely, written in Indonesian, or the test result was not sent. Respondents' characteristics as seen in Table 1, gender result was balanced, where female respondents were three people more than male respondents. For the age result, most respondents were 20 years old in 
which the chosen respondents were students in semester 4 and 6 that had passed English and economics theory courses. For the class result, it could be seen that respondents in semester 4 were bigger than respondents in semester 6 in the amount of 54 respondents. Morning class respondents were bigger that evening class respondents in the amount of 57 respondents.

Table 1. Respondents' Characteristics

\begin{tabular}{lllll}
\hline No. & Characteristics & Options & Total & Percentage \\
\hline 1. & Gender & Female & 45 & 51,7 \\
& & Male & 42 & 48,3 \\
\hline 2. & Age & a.18 & 1 & 1,1 \\
& & b. 19 & 30 & 34,5 \\
& c. 20 & 43 & 49,4 \\
& d. 21 & 9 & 10,3 \\
& e. 22 & 3 & 3,4 \\
& f. 23 & 1 & 1,1 \\
\hline 3. & Class & PM 402 & 21 & 24.1 \\
& & PM 403 & 21 & 24.1 \\
& & PM 602 & 5 & 5.7 \\
& & PM 603 & 10 & 11.5 \\
& & SM 401 & 12 & 13.8 \\
& & 6 & 6.9 \\
& & SM 601 & 6 & 9.2 \\
& & SM 602 & 8 & 4.6 \\
\hline
\end{tabular}

Source: the primary data were processed

Descriptive Analyses of Vocabulary, Reading Skill, and Writing Skill Variables

Vocabulary

Vocabulary average score was the highest in which it was 89,42 (Table 2). It was viewed that the vocabulary test results were rather different from reading and writing test results. The weakness of this online test is the possibility of respondents translating it so that the average vocabulary score is the highest. It is as stated by Nation in Solati-Dehkordi and Dehkardi (2016) that vocabulary relates to written form of a word.

Table 2. Average score of score total of Vocabulary, Reading, and Writing Variables

\begin{tabular}{ccc}
$\begin{array}{l}\text { Average score of } \\
\text { Vocabulary score total }\end{array}$ & $\begin{array}{l}\text { Average score of } \\
\text { Reading score total }\end{array}$ & $\begin{array}{l}\text { Average score of } \\
\text { Writing score total }\end{array}$ \\
\hline 89,42 & 66,89 & 67 \\
\hline \multicolumn{2}{c}{ Source: the primary data were processed }
\end{tabular}




\section{Reading Skill}

The average score of Reading score total was 66,89 (Table 2). It showed medium understanding of English passages. Reading skill was the ability that was needed by students to understand English passage. This matter had impact on students' understanding in deepening management science, in which the recent literature sources were journal articles that were mostly in English. It is also stated by Krashen in Khoirunissa and Safitri (2018) that continuous reading can enhance English skill performance including writing.

\section{Writing Skill}

In this writing test, there was weakness in which the test was conducted online during Covid -19 pandemic period. During data collection, there were several mistakes, such as the respondents misread the instruction so they wrote in Indonesian and the writing was less than 8-10 sentences. Hence, some respondents were contacted via Whatsapp group to revise their writing and submit again their writing in English and to write with adequate total sentences as written in the instruction. It is also stated by Brown (2007) that writing needs process starting from making draft until it becomes product. There are several assessment criteria in giving writing score, such as content $(66,79)$, grammar $(65,57)$, generic structure $(65,95)$, and originality $(70,25)$. The average score results of 87 respondents was 67 (Table 3). Hence, if it was compared to reading scores (Table 2), sub writing skill scores differences were not too high with other variables.

Table 3. Average score of Sub Variables of Writing Skill total score

\begin{tabular}{cccccc}
$\begin{array}{c}\text { Content } \\
\text { Average }\end{array}$ & $\begin{array}{c}\text { Grammar } \\
\text { Average }\end{array}$ & $\begin{array}{c}\text { Generic } \\
\text { Structure } \\
\text { Average }\end{array}$ & $\begin{array}{c}\text { Originality } \\
\text { Average }\end{array}$ & $\begin{array}{c}\text { Total Score } \\
\text { Average }\end{array}$ & Average \\
\hline 66,79 & 65,57 & 65,95 & 70,25 & 268,57 & 67
\end{tabular}

Source: the primary data were processed

\section{Normality Test}

Before conducting the statistics test, multivariate normality assumption was conducted. It means each variable and all linear combinations were distributed normally. If this assumption was accepted, then residual value of this analysis was also distributed normal and independent. Screening towards normality data was the first step that needs to be done in each multivariate analysis, especially if the aim is inference.

From the score of Kolmogorov-Smirnov and significance in Table 4, it can be seen that the data that distribute normal was reading skill with 
The Effect of Vocabulary towards Writing Skill with Reading Skill as Moderating Effect

significance value of $>0,01$, while vocabulary and writing skills did not distribute normal because the significance value was <0,01 (Ghozali, 2016).

Table 4. Normality Test

\begin{tabular}{|c|c|c|c|c|c|}
\hline \multicolumn{6}{|c|}{ One-Sample Kolmogorov-Smirnov Test } \\
\hline & & $\begin{array}{l}\text { Vocabulary } \\
\text { Total Score }\end{array}$ & $\begin{array}{l}\text { Reading } \\
\text { Total } \\
\text { Score }\end{array}$ & $\begin{array}{l}\text { Writing } \\
\text { Total } \\
\text { Score }\end{array}$ & $V^{*} \mathrm{R}$ \\
\hline $\mathrm{N}$ & & 87 & 87 & 87 & 87 \\
\hline \multirow{2}{*}{$\begin{array}{l}\text { Normal } \\
\text { Parameters }^{a}\end{array}$} & Mean & 89.43 & 66.90 & 67.1437 & 6077.59 \\
\hline & Std. Deviation & 12.882 & 19.188 & 19.85509 & 2097.600 \\
\hline \multicolumn{2}{|c|}{ Most $\quad$ Extreme Absolute } & .242 & .155 & .260 & .118 \\
\hline \multirow[t]{2}{*}{ Differences } & Positive & .206 & .092 & .145 & .059 \\
\hline & Negative & -.242 & -.155 & -.260 & -.118 \\
\hline \multicolumn{2}{|c|}{ Kolmogorov-Smirnov Z } & 2.257 & 1.445 & 2.430 & 1.103 \\
\hline \multicolumn{2}{|c|}{ Asymp. Sig. (2-tailed) } & .000 & .031 & .000 & .176 \\
\hline \multirow{3}{*}{$\begin{array}{l}\text { Monte Carlo Sig. } \\
\text { (2-tailed) }\end{array}$} & Sig. & $.000^{c}$ & $.026^{c}$ & $.000^{c}$ & $.158^{c}$ \\
\hline & $\begin{array}{ll}99 \% & \text { Lower } \\
\text { Confidenc Bound }\end{array}$ & .000 & .022 & .000 & .149 \\
\hline & $\begin{aligned} \text { e Interval } & \begin{array}{l}\text { Upper } \\
\text { Bound }\end{array}\end{aligned}$ & .000 & .030 & .000 & .167 \\
\hline
\end{tabular}

a. Test distribution is

Normal.

c. Based on 10000 sampled tables with starting seed 926214481.

$\mathrm{V}^{*} \mathrm{R}=$ Vocabulary*Reading;

Source: the primary data were processed

\section{Multicollinearity Test}

Multicollinearity test is aimed to test whether or not there is correlation among independent variables in regression model. There must be no correlation among independent variables in good regression model. If there is correlation among independent variables, then the variables are not orthogonal. Orthogonal variables are independent variables that the correlation score among independent variables is equal with zero (Ghozali, 2016). The way to detect multicollinearity is by analyzing correlation matrix among independent variables and counting Tolerance and VIF values as follows. In the correlation matrix (Table 5), the correlation between the independent variables is 0.301 . Because this correlation is still below $95 \%$, it can be said that there is no serious multicollinearity (Ghozali, 2016). 
Table 5. Multicollinearity Test with Correlation Matrix

\begin{tabular}{|c|c|c|c|c|}
\hline \multicolumn{5}{|c|}{ Coefficient Correlations $^{a}$} \\
\hline \multirow[b]{2}{*}{ Model } & & & \multicolumn{2}{|c|}{ Reading Total Vocabulary } \\
\hline & & & Score & Total Score \\
\hline \multirow[t]{4}{*}{1} & Correlations & Reading Total Score & 1.000 & -.301 \\
\hline & & $\begin{array}{l}\text { Vocabulary Total } \\
\text { Score }\end{array}$ & -.301 & 1.000 \\
\hline & Covariances & Reading Total Score & .016 & -.007 \\
\hline & & $\begin{array}{ll}\text { Vocabulary } & \text { Total } \\
\text { Score } & \end{array}$ & -.007 & .030 \\
\hline
\end{tabular}

a. Dependent Variable: Writing Total Score

Source: the primary data were processed

Table 6. Multicollinearity Test by counting Tolerance dan VIF

\begin{tabular}{llll}
\hline \multirow{2}{*}{ Model } & & \multicolumn{2}{l}{ Collinearity Statistics } \\
\cline { 2 - 4 } & & Tolerance & VIF \\
\hline 1 & (Constant) & & \\
\cline { 2 - 4 } & Vocabulary Total Score & .831 & 1.203 \\
\cline { 2 - 4 } & Reading Total Score & .717 & 1.395 \\
\hline
\end{tabular}

a. Dependent Variable: Writing Total Score

Source: the primary data were processed

Tolerance score counting shows that there is no independent variable that has tolerance value less than 0,1 which means that there is no correlation among independent variables. This counting result of Variance Inflation Factor (VIF) also shows the same matter in which there is no any single independent variable that has VIF score more than 10 . Hence, it can be concluded that there is no multicollinearity among independent variables in regression model (Table 6).

\section{Heteroscedasticity Test}

Heteroscedasticity test is aimed to test whether or not there was variance dissimilarity from one residual observation to other residual observations. If variance from one observation to other observations is constant, then it is 
homoscedasticity. If it is different, it means heteroscedasticity. Good regression model is homoscedastiticy or there is no heteroscedasticity (Ghozali, 2016).

One of heteroscedasticity tests is Park test that shows variants (s2i) is the function of independent variables (Ghozali, 2016) that is stated in equation:

$$
\sigma^{\wedge} 2 i=a X i \beta
$$

This equation becomes linear with logarithmic equation, in which it becomes:

$$
\operatorname{Ln} \sigma^{\wedge} 2 i=a+\beta \operatorname{LnXi+vi}
$$

Since $s^{\wedge} 2 \mathrm{i}$ is generally unknown, then it is predicted by using residual as proxy, then it becomes:

$$
\text { Ln Res_1SQ }=\propto+\beta \operatorname{LnXi+vi}
$$

\begin{tabular}{|c|c|c|c|c|c|c|c|}
\hline \multicolumn{8}{|c|}{ Coefficients ${ }^{a}$} \\
\hline & & & \multicolumn{2}{|c|}{$\begin{array}{l}\text { Unstandardized } \\
\text { Coefficients }\end{array}$} & \multirow{2}{*}{$\begin{array}{l}\text { Standardized } \\
\text { Coefficients } \\
\text { Beta }\end{array}$} & \multirow[b]{2}{*}{$\mathrm{t}$} & \multirow[b]{2}{*}{ Sig. } \\
\hline \multicolumn{2}{|c|}{ Model } & & B & Std. Error & & & \\
\hline \multirow[t]{3}{*}{1} & (Constant) & & 2.203 & 1.301 & & 1.693 & .094 \\
\hline & $\begin{array}{l}\text { Vocabulary } \\
\text { Score }\end{array}$ & Total & .031 & .016 & .226 & 1.973 & .052 \\
\hline & $\begin{array}{l}\text { Reading } \\
\text { Score }\end{array}$ & Total & -.018 & .011 & -.202 & -1.636 & .106 \\
\hline
\end{tabular}

Table 7. Heteroscedasticity Test

a. Dependent Variable: LnRES_1SQ

Source: the primary data were processed

Hence, the result of Ln Res_1SQ $=\alpha+\beta 1 \mathrm{TV}+\beta 2 \mathrm{TG}+\beta 3$ TR is in Table 7. If beta parameter coefficient of that regression equation is significant statistically, this shows that empirical data model is estimated that there is heteroscedasticity. If beta parameter coefficient of that regression equation is not significant statistically, it means that there is no heteroscedasticity in regression model, or in other words homoscedasticity assumption cannot be rejected. In Table 7 it can be seen that the parameter coefficients for the independent variables are not significant, it can be concluded that the regression model does not have heteroscedasticity.

\section{Validity Test}

Validity in this research is to measure validity of vocabulary, reading, and writing tests. It is done by conducting bivariate correlation among each 
test question score and variable total score. Because the instrument that is used in this research is test and not questionnaire, then each question is still included in the analysis. From the results of the correlation between the score of the questions with the total score of the variable, the vocabulary test No. 17 and reading tests no. 2 and 8 were not significant or invalid so they were excluded from further analysis.

Table: 8 Validity Test

\begin{tabular}{llll}
\hline \multicolumn{1}{c}{ Question No. } & \multicolumn{1}{c}{ Vocabulary } & \multicolumn{1}{c}{ Reading } & Writing \\
\hline 1 & $.333^{* *}$ & $.220^{*}$ & $.989^{* *}$ \\
\hline 2 & $.638^{* *}$ & .194 & $.989^{* *}$ \\
\hline 3 & $.611^{* *}$ & $.490^{* *}$ & $.989^{* *}$ \\
\hline 5 & $.363^{* *}$ & $.586^{* *}$ & $.921^{* *}$ \\
\hline 6 & $.458^{* *}$ & $.365^{* *}$ & 1 \\
\hline 7 & $.458^{* *}$ & $.498^{* *}$ & \\
\hline 8 & $.664^{* *}$ & $.400^{* *}$ & \\
\hline 9 & $.700^{* *}$ & .164 & \\
\hline 10 & $.803^{* *}$ & $.614^{* *}$ & \\
\hline 11 & $.458^{* *}$ & $.612^{* *}$ & \\
\hline 12 & $.436^{* *}$ & 1 & \\
\hline 14 & $.436^{* *}$ & & \\
\hline 15 & $.585^{* *}$ & \\
\hline 16 & $.554^{* *}$ & \\
\hline 17 & $.504^{* *}$ & \\
\hline 18 & $.259^{* *}$ & \\
\hline 19 & $.333^{* *}$ & \\
\hline 20 & $.319^{* *}$ & \\
\hline
\end{tabular}

${ }^{* *}$ Correlation is significant at the 0.01 level (2-tailed)

Source: the primary data were processed

\section{Reliability Test}

Reliability in this research is used to measure consistency of right or wrong answers in vocabulary and reading test variables. Whereas, the consistency of writing variable is seen among assessment criteria. The result of reliability test can be seen in Table 9 as follows. From Cronbach's Alpha, it can be seen that there is quite good reliability in the vocabulary and writing tests, but not good 
in the reading test. A construct is said to be reliable if the Cronbach Alpha value is > 0.7 (Nunnnally, 1994 in Ghozali, 2016).

Table: 9 Reliability Statistics, Cronbach Alpha

Reliability Statistics, Cronbach Alpha

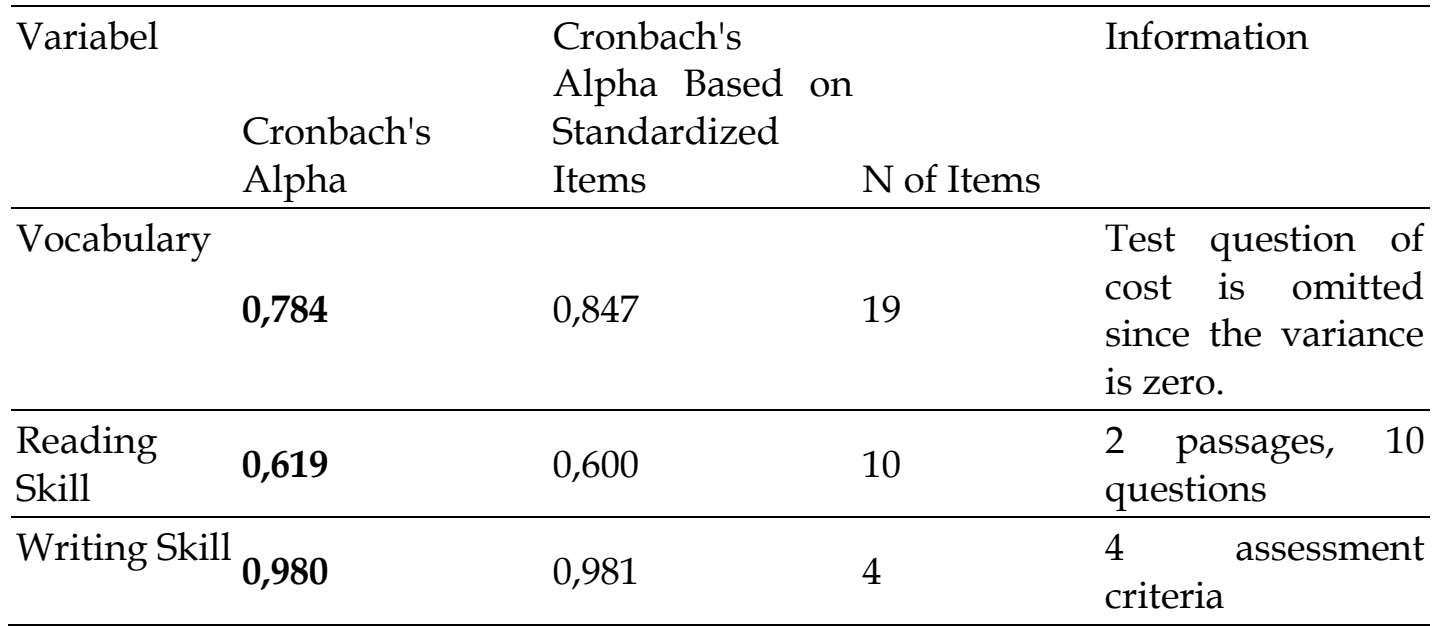

Source: the primary data were processed

The Effect Analysis of Vocabulary towards Writing Skill with Reading Skill as Moderator Variable by using Moderated Regression Analysis (MRA)

Moderated Regression Analysis uses analytic approach to maintain sample integrity and give basis to control the influence of moderator variable. In order to use MRA with one predictor variable $(X)$, then it must be compared with three regression equations to determine the type of moderator variable (Ghozali,2016; Sekaran \& Bougie, 2017). Moderator regression equation of Reading skill uses Moderated Regression Analysis (MRA). To use MRA with one predictor variable $(X)$, then it is compared with three regression equations to determine the type of moderator variable. Here are the three equations: $X 1$ : Vocabulary towards Y: Writing Skill, Z: Reading Skill.

The Effect Analysis of Moderator Variable Reading Skill towards the relation of Vocabulary and Writing Skill (Hypotheses 1 and 2 Testing)

In order to test moderating effect of reading skill in the relation of vocabulary and writing skill, it is compared among equation 1 towards equations 2 and 3. 
Table 10. Equation $1, W S=\alpha+\beta 1$ Vocabulary $+\varepsilon$

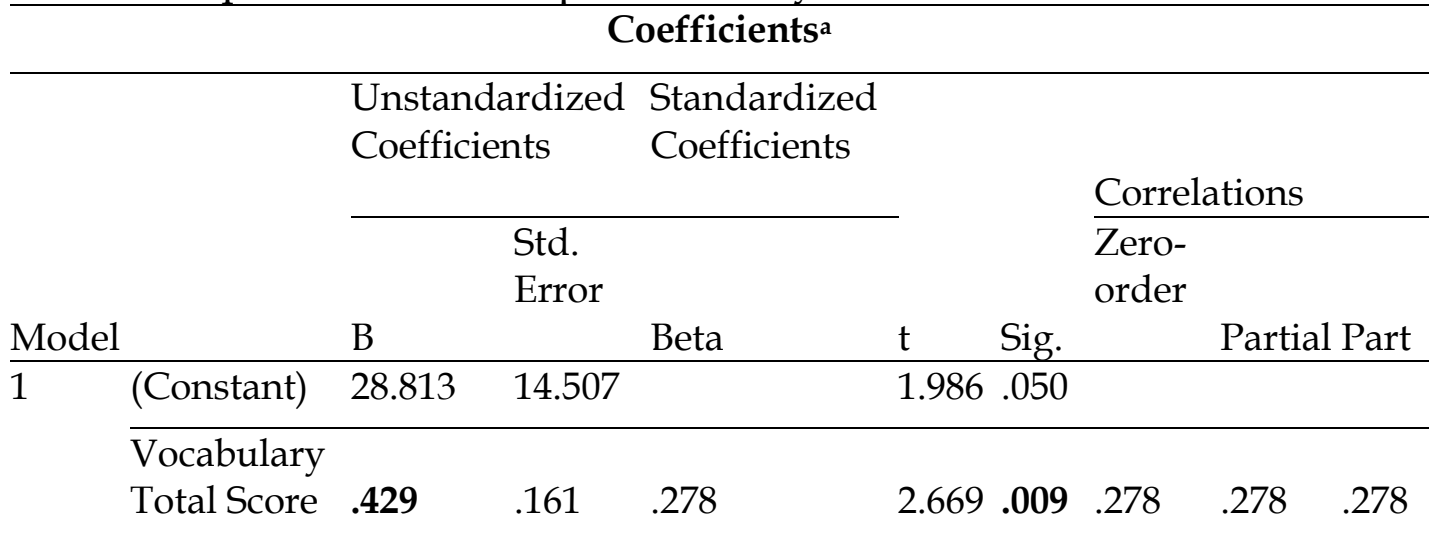

a. Dependent Variable:Writing Total Score

Source: the primary data were processed

From the result of regression equation 1, then the output of regression equation is: $W S=28,813+0,429$ Vc.

Table 11. Equation $2, W S=\alpha+\beta 1$ Vocabulary $+\beta 2 R S+\varepsilon$

\begin{tabular}{|c|c|c|c|c|c|c|c|c|c|}
\hline \multicolumn{10}{|c|}{ Coefficients ${ }^{a}$} \\
\hline \multirow{2}{*}{\multicolumn{2}{|c|}{ Model }} & \multicolumn{2}{|c|}{$\begin{array}{l}\text { Unstandardized } \\
\text { Coefficients }\end{array}$} & \multirow{2}{*}{$\begin{array}{l}\text { Standardized } \\
\text { Coefficients } \\
\text { Beta }\end{array}$} & \multirow[b]{2}{*}{$\mathrm{t}$} & \multirow[b]{2}{*}{ Sig. } & \multicolumn{3}{|c|}{ Correlations } \\
\hline & & B & $\begin{array}{l}\text { Std. } \\
\text { Error }\end{array}$ & & & & $\begin{array}{l}\text { Zero- } \\
\text { order }\end{array}$ & Partial & Part \\
\hline \multirow[t]{3}{*}{1} & (Constant) & 25.720 & 14.425 & & 1.783 & .078 & & & \\
\hline & $\begin{array}{l}\text { Vocabulary } \\
\text { Total Score }\end{array}$ & .308 & .172 & .200 & 1.790 & .077 & .278 & .192 & .184 \\
\hline & $\begin{array}{l}\text { Reading } \\
\text { Total Score }\end{array}$ & .207 & .116 & .200 & 1.793 & .077 & .278 & .192 & .184 \\
\hline
\end{tabular}

a. Dependent Variable: Writing Total Score

Source: the primary data were processed

From the regression result 2 , then the output of regression result is: WS $=25,720+0,308 \mathrm{Vc}+0,207$ RS. 
The Effect of Vocabulary towards Writing Skill with Reading Skill as Moderating Effect

Table 12. Equation $3, W S=\alpha+\beta 1$ Vocabulary $+\beta 2 R S+\beta 3$ Vocabulary $\times R S+\varepsilon$

\begin{tabular}{|c|c|c|c|c|c|c|c|}
\hline \multicolumn{8}{|c|}{ Coefficients $^{a}$} \\
\hline & & & \multirow{2}{*}{\multicolumn{2}{|c|}{$\begin{array}{l}\text { Unstandardized } \\
\text { Coefficients }\end{array}$}} & \multirow{3}{*}{$\begin{array}{l}\text { Standardized } \\
\text { Coefficients } \\
\text { Beta } \\
\end{array}$} & \multirow[b]{3}{*}{$\mathrm{t}$} & \multirow[b]{3}{*}{ Sig. } \\
\hline & & & & & & & \\
\hline \multicolumn{2}{|c|}{ Model } & & $\mathrm{B}$ & Std. Error & & & \\
\hline \multirow[t]{4}{*}{1} & (Constant) & & -8.706 & 39.792 & & -.219 & .027 \\
\hline & $\begin{array}{l}\text { Vocabulary } \\
\text { Score }\end{array}$ & Total & .694 & .450 & .450 & 1.542 & .127 \\
\hline & $\begin{array}{l}\text { Reading } \\
\text { Score }\end{array}$ & Total & .899 & .754 & .868 & 1.192 & .023 \\
\hline & $\mathrm{V}^{*} \mathrm{R}$ & & -.008 & .008 & -.805 & -.928 & .006 \\
\hline
\end{tabular}

a. Dependent Variable: Writing Total Score

Source: the primary data were processed

From the regression equation result, then the regression equation output is: $W S=-8,706+0,694 \mathrm{Vc}+0,899 \mathrm{RS}-0,008 \mathrm{~V} * \mathrm{R}$.

\section{DISCUSSION}

\section{Classical Assumption Tests}

In normality test, vocabulary and writing that did not distribute normal because of the weakness of the test in which it was conducted online. Furthermore, for the need of moderating effect measurement, then data $V^{*} R$ also showed significance value $>0,01$ which means the data distributed normal.

In multicollinearity test, it was based on the result of correlation among independent variables above (-0.301, which is below $95 \%)$, then it could be stated that there was no multicollinearity.

In heteroscedasticity test, there was no parameter coefficient that was significant in independent variable. Hence, it could be concluded that there was no heteroscedasticity in the regression model.

\section{Validity and Reliability}

From the test in Table 8, it can be seen that all test questions have significant correlation with total score. There is only one question no. 2 in reading variable that is not valid with significance $0,073>0,05$.

Cronbach Alpha is seen that vocabulary $(0,847)$ has been good. Whereas, reading skill is less good $(0,6)$. For writing skill, it has been very good $(0,981)$ for reliability. 


\section{Regression}

From the result of regression equation 1 , the equation is WS $=28,813+0,429 \mathrm{Vc}$. It can be seen that vocabulary has positive significant effect $(\operatorname{sig} 0,009<0,05)$ towards writing skill. It is as stated by Smith in Nurdini and Marlina (2017) states that readers search in the dictionary for the words that they do not know the meaning while reading. This also supports Hastuti's research (2015) in which vocabulary can increase writing. This result also states that hypothesis 1 that is vocabulary has positive significant effect towards writing skill is accepted. This answers the first research question.

From the regression result 2 , the equation is $W S=25,720+0,308$ $\mathrm{Vc}_{\mathrm{c}}+0,207 \mathrm{RS}$. It can be seen that significance $\beta 2$ is $0,077>0,05$. Hence, reading skill has positive impact but not significant $(\beta 2=0)$ towards writing skill. It almost supports Aida and Widiyati' research (2020) in which reading improves writing.

The regression equation output is: $\mathrm{WS}=-8,706+0,694 \mathrm{Vc}+0,899 \mathrm{RS}-0,008$ $V^{*} \mathrm{R}$. From equation 2 and 3 above, it can be seen that significance $\beta 3$ is $0,006<0,05(\beta 2=0, \beta 3 \neq 0)$. Hence, reading skill is pure moderator variable that moderates the influence of vocabulary towards writing skill. It is as stated by Krashen in Khoirunissa and Safitri (2018) states that continuous reading can enhance English skill performance including writing. It is also stated by Dehkordi and Salehi (2016) who did a research on impact of explicit vocabulary instruction on writing achievement in which the result was more practice on vocabulary productivity was needed for writing. This supports the research done by Dehkordi and Salehi (2016). This result also states that hypothesis 2 , that is reading skill has a role as moderator in the relation of vocabulary and writing skill is accepted. This answers the second research question.

It means writing skill increases with the increase of vocabulary, and if reading skill is strengthened, the more frequent reading and training the ability to understand passage, then it increases positive effect of vocabulary towards writing skill.

\section{CONCLUSION AND SUGGESTION}

From the analysis result, it can be concluded in two parts. Hypothesis 1 that is vocabulary has positive significant effect towards writing skill is accepted. This matter is accepted since if a person has rich vocabularies, then he or she will be free in placing his or her ideas in the form of writing. Hypothesis 2 that is reading skill moderates between vocabulary and writing skill can be accepted. It means reading skill can influence the relation of vocabulary and writing skill. This can be understood with the consideration that a person who masters vocabulary will increase his or her writing. The limitation of this research was the test was conducted online during pandemic era in which the 
test results could not represent fully. Further research can focus on the experimental research of vocabulary, reading, and writing. Experimental research is conducted directly in the classroom by minimizing the possibility of bias so that weaknesses in research via online tests can be corrected.

\section{ACKNOWLEDGMENTS}

The writers would like to thank to Institute for Research and Community Service of Universitas Katolik Musi Charitas, Palembang, South Sumatera for the support and fund to conduct this study in the university.

\section{REFERENCES}

Aida, S.N. \& Widiyati, E. (2020). Extensive Reading to Improve Students' Writing of Explanation Text. Journal of English Education, Literature, and Culture, 5(1), 109-117

Alqahtani, M. (2015).The Importance of Vocabulary in Language Learning and How to be Taught. The International Journal of Teaching and Education, 3(3), 21-34

Ariana. (2018).Improving Students ${ }^{\text {e }}$ Vocabulary Learning through Extensive Reading (A Study of Students in Muhammadiyah University of Makasar. ELITE Journal, 5(1), 90-110.

Brown, H.G. (2007). Teaching by Principles: An Interactive Approach to Language Pedagogy. New York: Pearson Education.

Creswell, J.W. (2012). Educational Research: Planning, Conducting, and Evaluating Quantitative and Qualitative Research. Boston: Pearson Education, Inc.

Dehkordi, S.A.S \& Salehi, H. (2016). Impact of Explicit Vocabulary Instruction on Writing Achievement of Upper-Intermediate EFL Learners. International Education Studies, 9(4), 141-154

Ghozali,I. (2016). Aplikasi Analisis Multivariate dengan program IBM SPSS 23.

Edisi 8. Semarang: Badan Penerbit Universitas Diponegoro.

Hastuti, S.D.S. (2015). The Influence of Vocabulary and Grammar Mastery on the Students ${ }^{\text {ee }}$ Writing Skill at Yogyakarta State University. Jurnal Media Wisata, 13(1), 179-18

Khairunas, S, Pratama, R.M.D., \& Iswanto, A. (2019). The Effect of Learning Motivation and Vocabulary Mastery towards Studentse Writing Skill in Argumentative Text at Private Senior High School in Kabupaten Serang. Jurnal Wanastra, 11(1), 37-46

Khoirunnisa \& Safitri, I.D. (2018). Reading Habits and Its Effect on Academic Writing Skill: A Study of Master Degree Students. Journal of English Language and Education, 4(1), 43-50. 
Nurdini, H \& Marlina, M. (2017). Vocabulary Journal as a Learning Tool for Students in Learning Vocabulary through Reading at Junior High School. Journal of English Language Teaching, 6(1), 272-285

Sekaran, U. \& Bougie, R. (2017). Metode Penelitian Untuk Bisnis. Edisi 6, Buku 2. Jakarta: Penerbit Salemba 4

Solati-Dehkordil, S.A. \&Salehi, H. (2016). Impact of Explicit Vocabulary Instruction on Writing Achievement of Upper-Intermediate EFL Learners.International Education Studies, 9(4), 141 - 154.

Thornbury, S. (2002). How to Teach Vocabulary. Essex: Pearson Education Limited. 